\title{
A case of a solitary form of Castleman disease: ten-year follow-up
}

\section{Przypadek chorego z postaciq zlokalizowanq choroby Castlemana: 10-letnia obserwacja}

\author{
Grzegorz Turek', Joanna Reszeć', Jan Kochanowicz', Adam Hermanowicz', Zenon Mariak' \\ 'Department of Neurosurgery, Medical University of Bialystok, Bialystok, Poland \\ 2Department of Medical Pathomorphology, Medical University of Bialystok, Bialystok, Poland
}

Neurologia i Neurochirurgia Polska 2013; 47, 2: 179-183

DOI: 10.5114/ninp.2013.34636

\begin{abstract}
Castleman disease (CD) is a rare atypical lymphoproliferative process of obscure pathogenesis. An intracranial localization of the condition is extremely rare. We present a case of a 29-year-old man, who harbored an intracranial plasma cell variant of $\mathrm{CD}$ in the form of a tumor mimicking meningioma and was followed up to 10 years after surgical excision of the lesion. The histopathological examination showed massive infiltration of mononuclear cells, composed mainly of lymphocytes and matured plasmocytes, as well as many small thin-walled vessels surrounded with plasma cells and lymphocytes. This picture was consistent with a plasma cell type of CD. Ten-year follow-up supports a notion that total surgical excision of the solitary intracranial infiltration is curative in plasma cell type of CD.
\end{abstract}

Key words: Castleman disease, meningioma-like lesion, surgical treatment.

\section{Introduction}

Castleman disease (CD, also known as giant lymph node hyperplasia) is a rare lymphoproliferative process described for the first time in 1956 by Benjamin Castleman as a thymoma-like lesion localized mediastinally [1]. Subsequent reports have described similar lesions localized in the abdomen, neck, lung, and the axilla, both

\section{Streszczenie}

Choroba Castlemana jest rzadkim, atypowym procesem limfoproliferacyjnym o niejasnej etiologii i patogenezie. Postać o lokalizacji wewnątrzczaszkowej rozpoznaje się nadzwyczaj rzadko. W pracy zaprezentowano przypadek 29-letniego mężczyzny, u którego przedoperacyjnie stwierdzono zmianę „,oponiakopodobną", jednak badanie histopatologiczne ujawniło wewnątrzczaszkową postać choroby Castlemana o typie plazmatycznokomórkowym. Chorego obserwowano przez 10 lat po usunięciu guza. W badaniu histopatologicznym stwierdzono naciek zapalny złożony głównie z limfocytów oraz dojrzałych plazmocytów, a także liczne cienkościenne naczynia otoczone komórkami plazmatycznymi i limfocytami. Obraz histopatologiczny jednoznacznie wskazywał na postać plazmatycznokomórkową choroby Castlemana. Dziesięcioletnia obserwacja po usunięciu zmiany wskazuje, że całkowite wycięcie guza może zapewnić trwały efekt leczniczy.

Słowa kluczowe: choroba Castlemana, zmiana oponiakopodobna, leczenie operacyjne.

in nodal and non-nodal tissues. Clinically, CD is classified as localized/solitary or multicentric $[2,3]$. There are also two distinctive histological forms of CD: first, a hyaline-vascular form, which occurs in $85-90 \%$ of localized tumors; and second, a plasma cell form, which affects $80-90 \%$ of patients with multicentric $\mathrm{CD}[2,3]$.

Castleman disease may invade the central nervous system; however, this localization is extremely rare. Since

Correspondence address: Grzegorz Turek, MD, Department of Neurosurgery, Medical University of Bialystok, Skłodowskiej-Curie 24a, 15-276 Bialystok, Poland, e-mail: turekgrzegorz@vp.pl

Received: 2.02.2012; accepted: 17.10.2012 
its first description in 1983 by Lacombe et al., only a few case reports have been published [4-10]. Intracranial lesions were found to be solitary [5-9]; however, they could also constitute part of a multicentric angiofollicular lymphoid hyperplasia [10]. We present a patient who was referred to us with a diagnosis of intracranial meningioma, which eventually turned out to be a case of localized intracranial CD. What makes our case unique among other similar reports is the long period of follow-up, which amounts to 10 years.

\section{Case report}

A 29-year-old man was treated in our department in 2003, admitted after two incidents of syncope, which had occurred 6 months and 10 days before admission. He was complaining of severe headache, which he had suffered once to twice a week for the past 2 years. Before that time, he was healthy, did not take any medications, and smoked approximately 20 cigarettes daily. Blood morphology (including blood smear), urine analysis, and other basic laboratory analyses were within the normal range, except for elevated concentration of $\mathrm{C}$ reactive protein $(40 \mathrm{mg} / \mathrm{L})$. HIV infection/AIDS has been excluded.

Computed tomography $(\mathrm{CT})$ revealed an irregular but distinct extra-axial mass $(6 \times 3 \mathrm{~cm})$, with a broad base adjoining the frontal bone (Fig. 1). The main bulk of the mass was on the right side but it crossed the midline and infiltrated the falx. The mass compressed the right frontal lobe and frontal horn and caused marked peritumoral brain edema. It enhanced after contrast injection, but no calcification was demonstrated. Based on the CT image, the tumor was diagnosed as meningioma and therefore further magnetic resonance imaging (MRI) was deemed unnecessary to opt for a surgical resection.

The lesion was reached through a bifrontal craniotomy and visually still resembled a meningioma with its soft consistency, yellow-brown color, and somewhat paler core. However, the consistency of the tumor was much softer than in typical meningioma. The arachnoid barrier was partly intact, and thus the lesion could be easily separated from the adjacent cortex. There was also a thin $(\sim 1 \mathrm{~mm})$ layer of tumor tissue extending into the epiarachnoid space along the brain surface up to $1-2 \mathrm{~cm}$ beyond its main mass. The tumor invaded the anterior third of the sagittal sinus and the adjacent dura mater of the frontal region. All the masses were removed totally with resection of the invaded segments of the dura, sagittal sinus, and falx. There was an episodic epileptic seizure in the postoperative phase; thereafter, the epilepsy could be successfully controlled pharmacologically. The patient was discharged on the $7^{\text {th }}$ day without neurological deficit. CT was performed 6 months and 7 years after the surgery and MRI after 9 years (Fig. 2). No tumor recurrence was demonstrated and the current year is about to close a 10-year long follow up period in which no signs of tumor recurrence have appeared.

The routine histopathological evaluation (HE) showed a dispersed infiltration with numerous mononuclear cells, composed mainly of lymphocytes and mature plasmocytes (Figs. 3A-B), as well as many small thin-walled vessels in the brain parenchyma (Fig. 4A). Plasma cells and lymphocytes surrounded all small vessels or infiltrated adjacent brain tissue (Figs. 4B-D). Differential diagnosis excluded plasmacytoma and B-cell lymphoma. Mitotic activity (MIB-1 expression) was very low (about 2\%). The picture was recognized as typical for a plasma cell type of CD.

After a plasma cell type of $\mathrm{CD}$ had been confirmed, the patient underwent further systemic examinations with whole-body CT scanning to exclude multifocal CD. Further laboratory examinations including tumor markers and immunoglobulin concentrations were with-

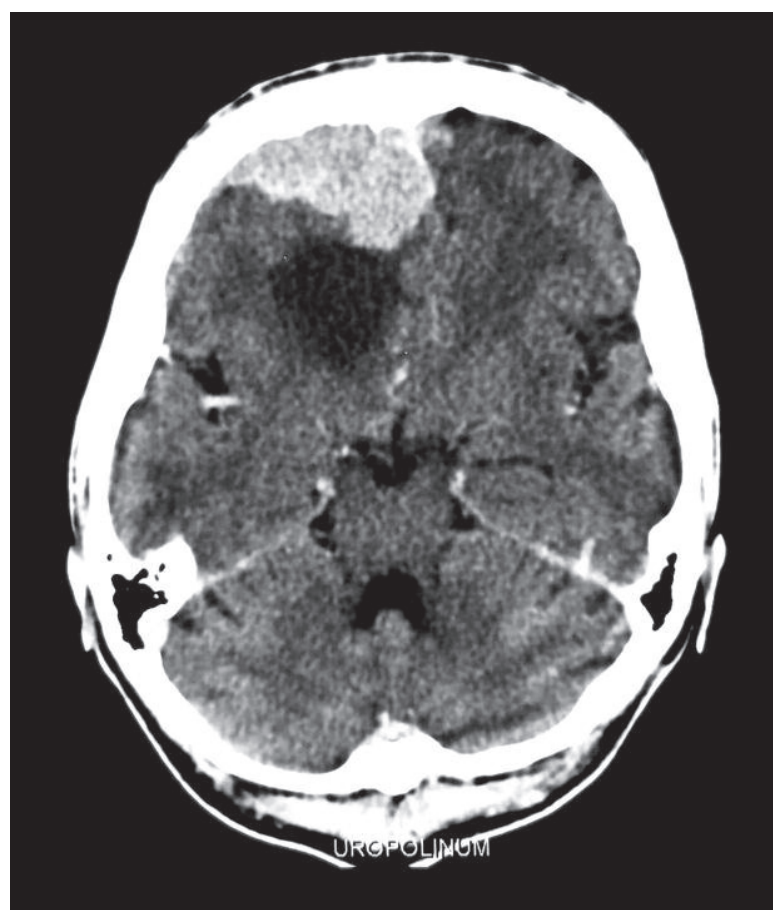

Fig. 1. Computed tomography scan showing an extra-axial mass with a broad base adjoining the frontal bone. The mass compresses the right frontal lobe and the frontal horn and causes a marked peritumoral brain edema. It enhanced after contrast injection but no calcifications were demonstrated 
in the normal range except for increased interleukin (IL)-6 and IL-10 concentration.

\section{Discussion}

Based on the $\mathrm{CT}$ or MRI picture, this localized form of $\mathrm{CD}$ belongs to the "tumor mimicking meningioma" group of lesions. Of course, the mass is by no means a kind of meningioma (in a case of plasma cell CD), rather constituting a localized aggregate of lymph nodes. Because the condition is so rare, preoperative differential diagnosis is very difficult, if at all possible. In previously described cases, the main feature of the $\mathrm{CT}$ was a homogeneously enhancing extra-axial mass with no calcifications and with a disproportionally marked peritumoral edema [6]. On MRI, the homogeneously enhancing mass was usually isointense in T1-weighted, T2-weighted, and FLAIR images, while possibly being hyperintense in diffusion-weighted imaging $[6,9]$. Sometimes, invasion into the sulcal space and dural enhancement can also be demonstrated. The mass arises from the dura matter or leptomeninges, the most common site of origin being located at the cerebral convexity followed by the parafalcine dura matter [9]. Similar radiological features were also found in our patient and, as in all other published cases, the final diagnosis was based on the histopathological evaluation and not on the cerebral imaging.

According to the literature, $70 \%$ of patients with solitary intracranial CD are women [4]. Also, there is a predilection to $\mathrm{CD}$ in patients suffering from HIV and human herpes virus 8 infections [2]. From a diagnostic point of view, it is worth noting that $50-90 \%$ of patients

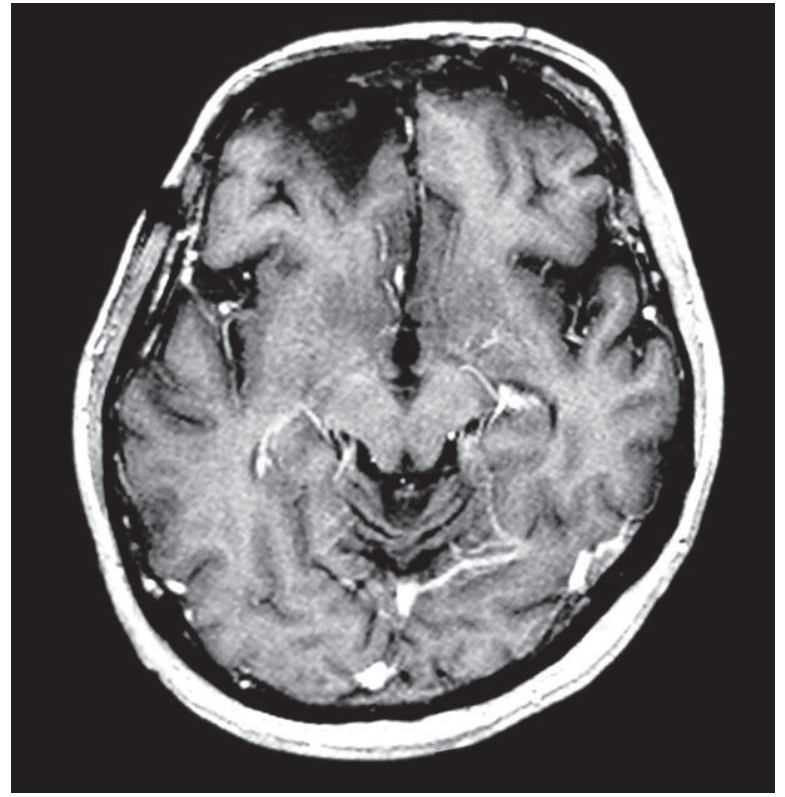

Fig. 2. Magnetic resonance imaging scan showing no tumor recurrence 9 years after surgery

with a plasma cell type $\mathrm{CD}$ demonstrate hematological disorders such as anemia, leukocytosis, hypergammaglobulinemia, and/or increased concentration of C-reactive protein (CRP) [2]. Particularly, the increased serum concentration of IL-6 is very important, and results in increased IL-6 expression by plasma cells [8]. In the present case, the concentrations of CRP, IL-6 and IL-10 were increased, but the examination was done postoperatively, after histopathological diagnosis.

In all other reported studies, the etiological diagnosis was made postoperatively and the patients were treat-
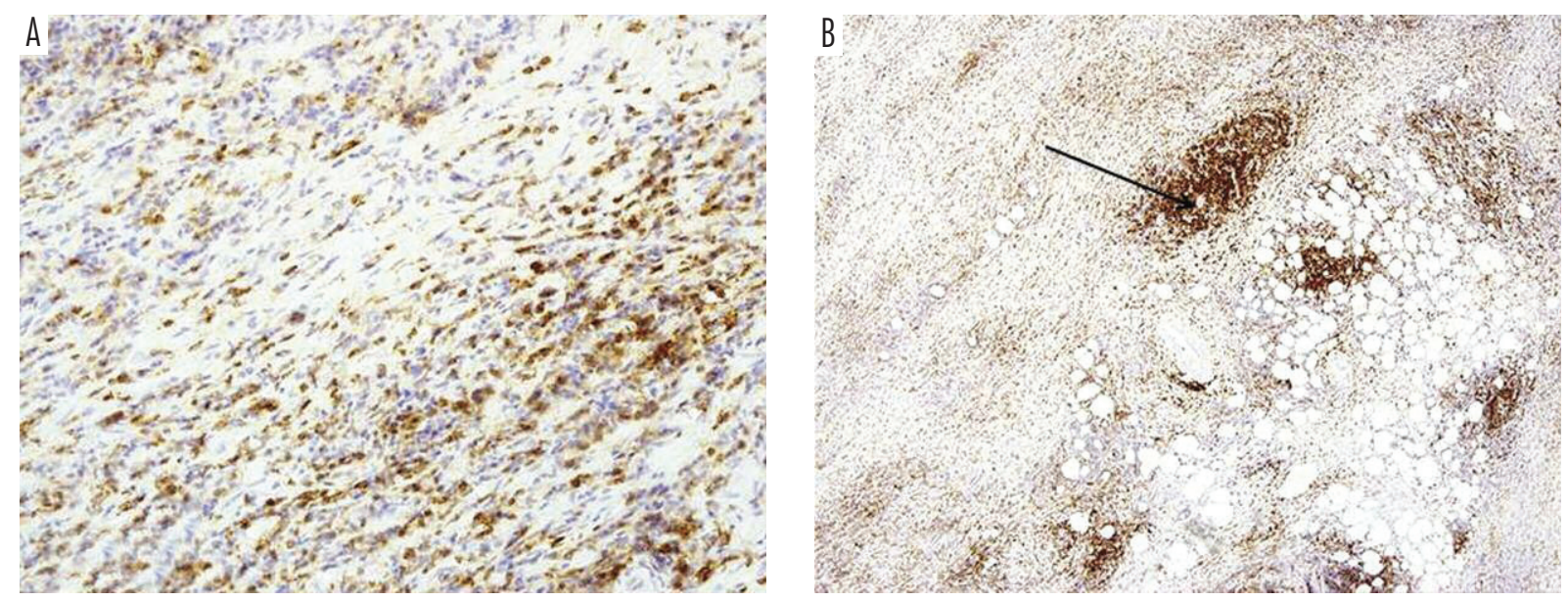

Fig. 3. (A) CD3 expression (infiltration of T cells) within the lesion $(\times 100)$; (B) CD138 expression in plasma cells surrounding small vessels $(\times 40)$ 

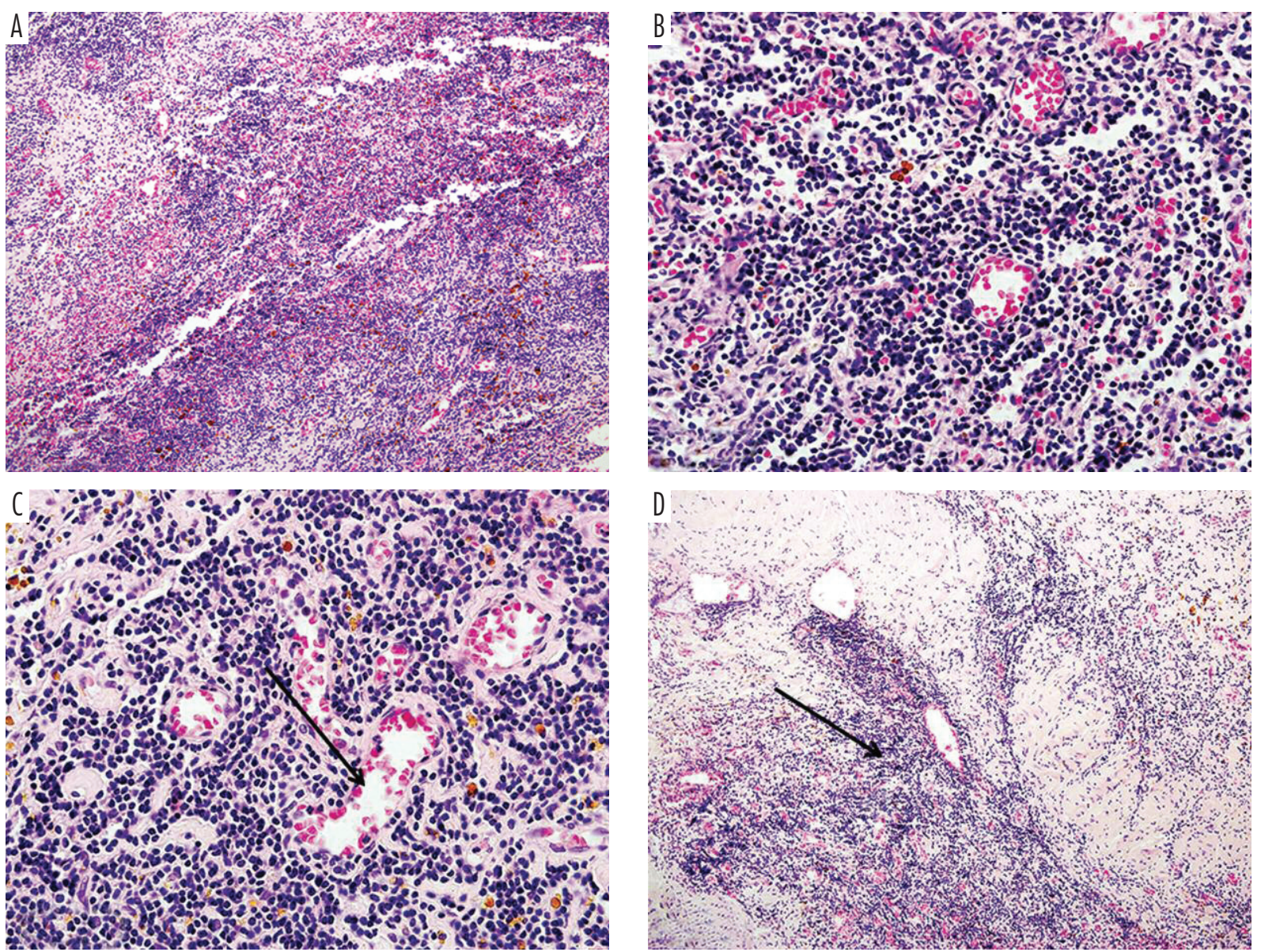

Fig. 4. (A) Marked inflammatory cell infiltration of the brain tissue (X 100); (B-D) dense infiltration surrounding small thin-walled, enlarged vessels (arrow in Fig. 4C), composed mostly of lymphocytes and many plasma cells (arrow in Fig. 4D) $(\times 200)$

ed surgically with no regrowth seen after total excision [5-9]. Nevertheless, obtaining an exact preoperative diagnosis could be of advantage because - in contrast to meningioma - also conservative therapeutic options can be considered in some patients with CD. Radiotherapy, steroids and cytotoxic agents (cyclophosphamide, chlorambucil) have proven effective, especially in the multicentric form of $\mathrm{CD}$, which generally features a worse prognosis $[2,6]$.

In spite of the potentially effective conservative approach, in all reported case studies, surgical treatment was attempted and reported to be effective. Nevertheless, the follow-up period in most reported cases was no longer than 3 years and was usually between several months and 2 years [4]. Only Lacombe et al. [7] (who first reported a case of solitary intracranial CD in 1983) followed their patient up to 8 years; similarly, Cummings et al. [5] reported a 5-year follow-up free of recurrence. Our 10-year follow-up is the longest in the literature and may support the conclusion that operative treatment of solitary $\mathrm{CD}$ provides a valuable and permanent therapeutic effect [11].

\section{Disclosure}

Authors report no conflict of interest.

\section{References}

1. Castleman B., Iverson L., Menendez V.P. Localized mediastinal lymphnode hyperplasia resembling thymoma. Cancer 1956; 9: 822-830.

2. McClain K.L., Natkunam Y., Swerdlow S.H. Atypical cellular disorders. Hematology Am Soc Hematol Educ Program 2004; 1: 283-296.

3. Waterston A., Bower M. Fifty years of multicentric Castleman's disease. Acta Oncol 2004; 43: 698-704.

4. Coca S., Salas I., Martinez R., et al. Meningeal Castleman's disease with multifocal involvement: a case report and review of literature. J Neurooncol 2008; 88: 37-41. 
5. Cummings T.J., Gong J.Z., Friedman A.H., et al. Castleman's disease confined to the leptomeninges. Ann Clin Lab Sci 2000; 30: $278-282$

6. Hashimoto H., Iida J., Hironaka Y., et al. Intracranial Castleman's disease of solitary form. Case report. J Neurosurg 1999; 90: 563-566

7. Lacombe M.J., Poirier J., Caron J.P. Intracranial lesion resembling giant lymph node hyperplasia. Am J Clin Pathol 1983; 80 721-723.

8. Mallik A.A., Katchy K.C., Clotan N. Solitary intracranial Castleman's disease, plasma cell variant: a case report. Med Princ Pract 2007; 16: 226-229.

9. Matsumura K., Nakasu S., Tanaka T., et al. Intracranial localized Castleman's disease. Case report. Neurol Med Chir (Tokyo) 2005; 45: 59-65.

10. Yoshida K., Suzuki T., Sakata T., et al. Successful treatment of multicentric Castleman's disease with intracranial and retroperitoneal tumors. Intern Med 2001; 40: 976-977.

11. Wilczak M., Kampioni M., Szmeja J. Castleman's disease a case report. Videosurgery Miniinv 2011; 6: 27-32. 